\title{
Discordance in the identification of juvenile pink shrimp (Farfantepenaeus brasiliensis and F. paulensis: Family Penaeidae): An integrative approach using morphology, morphometry and barcoding
}

\author{
S.S.A. Teodoro ${ }^{\mathrm{a}, *}$, M. Terossi $^{\mathrm{b}}$, F.L. Mantelatto ${ }^{\mathrm{b}}$, R.C. Costa ${ }^{\mathrm{a}, *}$ \\ a Laboratório de Biologia de Camarões Marinhos e Dulcícolas (LABCAM), Departamento de Ciências Biológicas, Faculdade de Ciências, Universidade \\ Estadual Paulista (UNESP), Av. Eng. Luiz Edmundo Corrijo Coube, 14-01, 17033-360 Bauru, SP, Brazil \\ ${ }^{\mathrm{b}}$ Laboratório de Bioecologia e Sistemática de Crustáceos (LBSC), Faculdade de Filosofia, Ciências e Letras de Ribeirão Preto (FFCLRP), Universidade de São \\ Paulo (USP), 14040-901, Ribeirão Preto, São Paulo, Brazil
}

\section{A R T I C L E I N F O}

\section{Article history:}

Received 12 October 2015

Received in revised form 30 May 2016

Accepted 8 June 2016

Handled by George A. Rose

Available online 23 June 2016

\section{Keywords:}

Brazil

Farfantepenaeus

Cytochrome oxidase I

Morphometry

Penaeoidea

Species discrimination

\begin{abstract}
A B S T R A C T
It is most difficult to identify the coexistent commercial pink shrimps Farfantepenaeus brasiliensis and Farfantepenaeus paulensis during the juvenile stage, when secondary sexual characteristics are still in the developing period. Differences in width and/or shape of the dorsal furrow on pleonite six has traditionally been the primary character used to discriminate juveniles of these two taxa, but is unreliable. This study aimed to test the hypothesis that the taxonomic morphological characteristics traditionally used to discriminate between these species are not effective for juveniles. Molecular analyses showed that the COI gene is an efficient marker for separating these two species and that traditional characteristics do not allow for the correct identification of juveniles of these species. In addition, we found that only $64 \%$ of juveniles identified a priori based on traditional morphological traits and subsequently verified molecularly were identified correctly. After molecular identification of the species, we searched for new morphological traits that could be used for reliable identification of juvenile and adult stages using morphometry and comparative morphology. The carapace length $(\mathrm{CL})$ ranged from 12.5 to $26.9 \mathrm{~mm}$ in F. brasiliensis and from 9.4 to $49.5 \mathrm{~mm}$ in F. paulensis. We affirmed the efficiency of COI as a molecular marker and identified a new morphological trait that will aid in the discrimination of juveniles of $F$. brasiliensis and F. paulensis. Contrary to our expectations, the characters identified by morphometric analysis were subtle and difficult to apply in field identification situations. However, when analyzing the external morphology of juveniles, it was possible to identify differences between the species in the anterior margin of gastrofrontal carina in relation to the rostrum teeth. In addition to corroborating the difficulty in identifying these two species, our study confirms the importance of the association between molecular and comparative morphology analyses in a fisheries and biodiversity context. Furthermore, we extended the geographic distribution of Farfantepenaeus subtilis through a new record from southern Cananéia, on the southern coast of São Paulo State.
\end{abstract}

(C) 2016 Elsevier B.V. All rights reserved.

\section{Introduction}

The penaeids Farfantepenaeus brasiliensis (Latreille, 1817) and F. paulensis (Pérez-Farfante, 1967) are two of the most exploited shrimp stocks off Brazil (Costa et al., 2008). These species represent approximately $18 \%$ of the total fished marine crustaceans $(57,344.8 \mathrm{t})$ along the Brazilian coast (IBAMA, 2011). Farfantepe-

\footnotetext{
* Corresponding authors.

E-mail addresses: sarahteodoro@gmail.com (S.S.A. Teodoro), mterossi@usp.br (M. Terossi), flmantel@usp.br (F.L. Mantelatto), rccosta@fc.unesp.br (R.C. Costa).

naeus brasiliensis and F. paulensis are both known as "pink shrimp", and usually no distinction is made between taxa during assessments of fishery stocks (Brisson, 1981; Chagas-Soares et al., 1995; IBAMA, 2011). These species are endemic to the western Atlantic coast: F. brasiliensis is distributed from North Carolina (USA) to Rio Grande do Sul (Brazil), and F. paulensis is restricted to an area from Bahia (Brazil) to Buenos Aires (Argentina) (Costa et al., 2003).

Considering the high morphological similarity between the two species, identification of adults is based on two specific characteristics: F. brasiliensis has a dorsal furrow on the sixth pleonite that resembles more of an ellipse and gradually increases an then tapers toward the posterior margin (Fig. 1a), and it has a black spot at the 

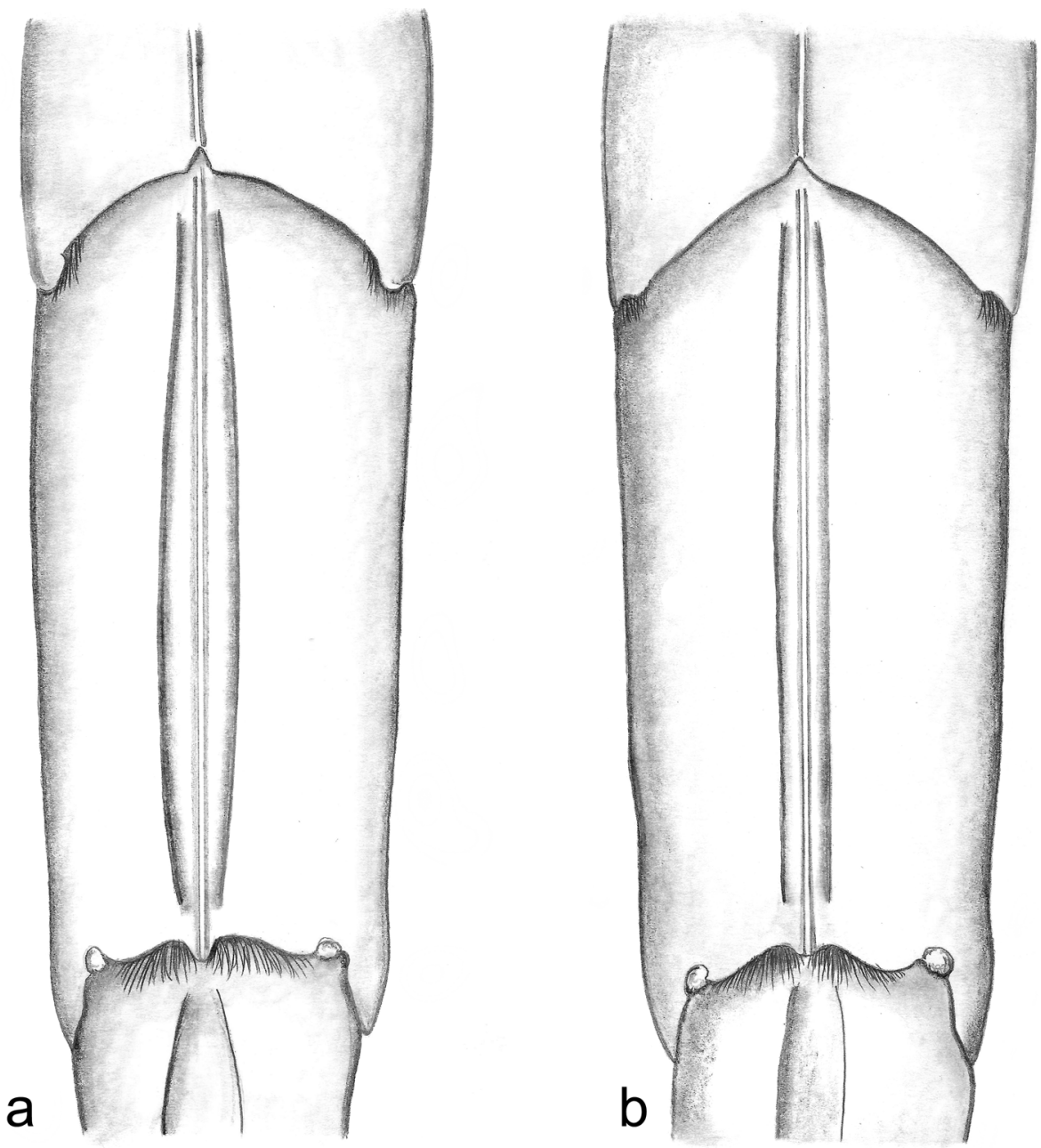

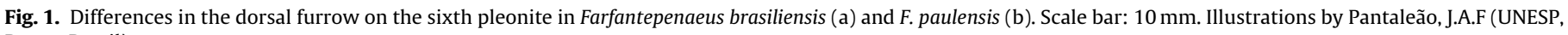
Bauru, Brazil).

junction of third and fourth pleonites (visible only if it is a fresh adult specimen) (Costa et al., 2003; Pérez-Farfante, 1969, 1970, 1971). Males have a petasma with a long distomedial projection and a curved dorsal region; females have the thelycum with the anterior portion of the sideplates covering the posterior process, i.e., they present an unexposed posterior process (Costa et al., 2003; Pérez-Farfante, 1969, 1970, 1971). By comparison, F. paulensis lacks the spot observed on the pleonites, the dorsolateral sulcus width is narrower and nearly uniform along its entire length (Fig. 1b) (Costa et al., 2003; Pérez-Farfante, 1969, 1970, 1971). Males have a petasma with a short distomedial projection and a small curved dorsal region and females have the thelycum with the anterior portion of the sideplates not covering the posterior process, i.e., they present an exposed posterior process (Costa et al., 2003; PérezFarfante, 1969, 1970, 1971). It is most difficult to differentiate pink shrimp of $F$. brasiliensis from $F$. paulensis during the juvenile stage, when secondary sexual characteristics are still developing. Thus, the only way to separate species is by observing the dorsal furrow of the sixth pleonite, as described above. In adult males, however, the distal region of the petasma often ruptures during trawling, which makes this character difficult to use for discrimination purposes (Costa et al., 2003), and the loss of the black spot on the pleonites after fixation of $F$. brasiliensis specimens in alcohol/formalin causes additional difficulty.

In a study performed in the Gulf of Mexico with other species of Farfantepenaeus, molecular techniques indicated that the use of "traditional" morphologic characteristics resulted in the misidentification of approximately 30\% of individuals of Farfantepenaeus duorarum (Burkenroad, 1939) and F. aztecus (Ives, 1891) (Ditty and Bremer, 2011). The authors also emphasized that the characteristics used for taxon identification are not always sufficient for the correct differentiation of species, highlighting the importance of the association between molecular analysis and comparative morphology in studies concerning diversity patterns, ecological issues and fishery management.

Other studies have discussed or illustrated diagnostic features useful for discrimination of adults of $F$. brasiliensis and F. paulensis (see Pérez-Farfante, 1969, 1970, 1971; Costa et al., 2003). In addition, May-Kú et al. (2005) described morphometric differences between early juvenile of $F$. brasiliensis and $F$. notialis (PérezFarfante, 1967). However, none of these studies jointly evaluated the two pink shrimp species fished along the southern and southeastern coasts of Brazil, F. brasiliensis and F. paulensis. In this context, our study aimed to test the hypothesis that traditional morphological characteristics are insufficient to reliably discriminate juveniles of $F$. brasiliensis and $F$. paulensis. The main objective was to employ a molecular test to determine whether the traditional morphological criteria used for a reliable identification of the two species are effective. If the molecular techniques indicated misidentification of individuals of both species, we searched for new morphological traits that could allow for reliable discrimination of juveniles and 
adults using morphometry and comparative morphology, considering possible differences between males and females.

\section{Material \& Methods}

\subsection{Sampling}

The samples were collected from three main localities off the coast of São Paulo State, Brazil: the northern (Ubatuba; $23^{\circ} 26^{\prime} \mathrm{S}, 45^{\circ} 04^{\prime} \mathrm{W}$ ), central (Santos; $2^{\circ} 57^{\prime} \mathrm{S}, 46^{\circ} 19^{\prime} \mathrm{W}$ ) and southern (Cananéia; $25^{\circ} 05^{\prime} \mathrm{S} ; 47^{\circ} 55^{\prime} \mathrm{W}$ ) regions (Fig. 2). We selected these regions to serve as a case study because both species, including small individuals (juveniles), are frequently targeted during fishery activities.

Specimens were captured with a commercial fishing boat equipped with trawl nets with mesh sizes of $20 \mathrm{~mm}$ and $18 \mathrm{~mm}$. After each trawling, the biological material was stored on ice and transported to the laboratory, where each specimen was first identified according to the morphological key (Costa et al., 2003). Each specimen was individually preserved in $75-90 \%$ alcohol and then stored in the Crustacean Collection of the Department of Biology, under the Faculty of Philosophy, Sciences and Letters at Ribeirão Preto, University of São Paulo (CCDB/FFCLRP/USP), Brazil. Additional specimens used in analysis were previously catalogued in CCDB collections from Rio Grande do Sul State (Fig. 2).

Specimens were first morphologically identified by two researchers (S.S.A. Teodoro and R.C. Costa) at species level, according to Costa et al. (2003). Sex identification was performed by observing the first pair of pleopods (Pérez-Farfante and Kensley, 1997; Costa et al., 2003) using a Zeiss ${ }^{\circledR}$ stereomicroscope with a zoom from $6.7 x$ to $45 x$. Then, molecular techniques were applied to confirm whether the identification was correct. The collection location and season were unknown to the identifier a priori, and the outcomes were compared (morphological identification versus molecular identification). Morphometric and comparative morphology techniques were applied only to specimens successfully sequenced, i.e., individuals with a confirmed molecular identity, thus ensuring a reliable evaluation of the characteristics that are traditionally used for species discrimination.

The carapace length (CL) was defined as the linear distance between corresponding to the orbital angle to the posterior margin of the carapace along the dorsal midline. Individuals with a $\mathrm{CL} \leq 22 \mathrm{~mm}$ (smaller individuals on which the morphological characteristics traditionally used for identification are more difficult to observe) were classified as "juveniles" (Lopes, 2012), whereas individuals (males and females) with $\mathrm{CL} \geq 22 \mathrm{~mm}$ (diagnostic characteristics easier to observe) were classified as "adults".

\subsection{Molecular analyses}

Molecular analyses included 103 total specimens (Table 1). The genetic material was obtained and processed in accordance with a SISBIO license for sampling and genetic analysis of decapods (N \# 11777-1, Issue Date: 09/16/2007, issued from CGEN to FLM, the coordinator of the Biota FAPESP Thematic project, Process \# 2010/50188-8). Considering the wide variability in its evolutionary rate (Moritz et al., 1987), the mitochondrial gene cytochrome oxidase I (COI) was chosen for molecular analysis to examine the occurrence of inter-population variation within decapod species, as has previously been performed in other studies of shrimp species (Carvalho-Batista et al., 2014; Gusmão et al., 2000; Terossi and Mantelatto, 2012; Vergamini et al., 2011). The COI gene is also used as a "barcode" for most extant animals (Hebert et al., 2003).

Tissue extraction, PCR amplification with specific primers, product cleanup, and sequencing were conducted following our laboratory protocols (Mantelatto et al., 2007, 2009), with specific modifications (Teodoro et al., 2015). Sequence editing was performed using the BioEdit program, version 7.0.9 (Hall, 1999). The DNA fragments were aligned using BLAST and the NCBI database assembly (http://blast.ncbi.ncbi.nlm.nih.gov/blast.cgi) to confirm their respective identities. Additional sequences from other species were used for comparison: two sequences were retrieved from GenBank (F. californiensis - NC_012738.1 and F. notialis - X84350.2) and two sequences of $F$. subtilis (CCDB 4717 - KF989462 and CCDB 4676 - KX421864) were generated in this study.

The analyses followed methods described by Vergamini et al. (2011) for comparison between species. The sequences were previously aligned with pre-defined parameters in ClustalW (Thompson et al., 1994) and were implemented in BioEdit 7.0.9. Then, a genetic divergence matrix was constructed based on the Kimura 2-parameter model (Kimura, 1980) in MEGA version 5 (Tamura et al., 2011). The number of haplotypes was calculated using DnaSP 4.10.9 (Rozas and Rozas, 1999), and the haplotype networks were constructed using a Median-Joining method in the program Network (Bandelt et al., 1999), with data preparation in DnaSP. For the adults, genetic differences in the studied regions were analyzed using Analysis of Molecular Variance (AMOVA) (Excoffier et al., 1992), separately considering the variations at each nucleotide site, in Arlequin 3.1 (Excoffier et al., 2005).

After the molecular analysis, voucher specimens that were molecularly identified were catalogued in the CCDB/FFCLRP/USP collection ( $F$. brasiliensis: accession numbers 4477, 4478, 4496, 4532; F. paulensis: 4482, 4483, 4484, 4679), and the sequences were stored in GenBank (F. brasiliensis: KF989360-KF989423; F. paulensis: KF989424-KF989461).

\subsection{Morphometry}

All the specimens (adults and juveniles) for which the molecular identity was verified were used for morphometric analysis. Although it is most difficult to identify species at the juvenile stage, we aimed to find a characteristic that would be reliable for discrimination of both juveniles and adults. Additionally, as morphometric techniques could be applied only in individuals with confirmed molecular identities, the addition of adult specimens to the analysis contributed to a more robust result because morphometric analyses require more individuals than molecular analysis.

\subsection{1. linear morphometry}

A digital caliper (accuracy of $0.01 \mathrm{~mm}$ ) was used for morphometric analysis. For each individual, the following measurements were obtained: $\mathrm{CL}$; carapace height $(\mathrm{CH})$; antennal scale length (ASL); length of the first (PL1), second (PL2), third (PL3), fourth (PL4), fifth (PL5) and sixth (PL6) pleonites; telson length (TEL); uropod endopodite length (UEL); and uropod exopodite length (EXL) (Fig. 3A). These measurements were adapted from those performed by Tzeng (2004), who studied the penaeid Parapenaeopsis hardwickii (Miers, 1878) and found that these traits are useful for morphometric studies. Regarding plate overlap, measurements were taken exactly as depicted in Fig. 3A, considering the curved abdomen of the species, from anterior to posterior margin of an individual pleon.

The allometric equation $\left(y=a x^{b}\right)$ was used to determine the b value, which is used for calculating the effect of CL variation (independent variable) on the separately measured body structures (dependent variables) (Tzeng, 2004). All of the size characteristics were standardized according to $\mathrm{Yi}^{*}=\mathrm{Yi}[\mathrm{X} / \mathrm{Xi}]^{\mathrm{b}}$, where $\mathrm{Yi}^{*}$ is the standardized size of the desirable feature, $\mathrm{Yi}$ is the size of the feature that will be standardized, $X$ is the mean carapace length of the sample, and $\mathrm{Xi}$ is the carapace length of the individual (Tzeng, 2004). 


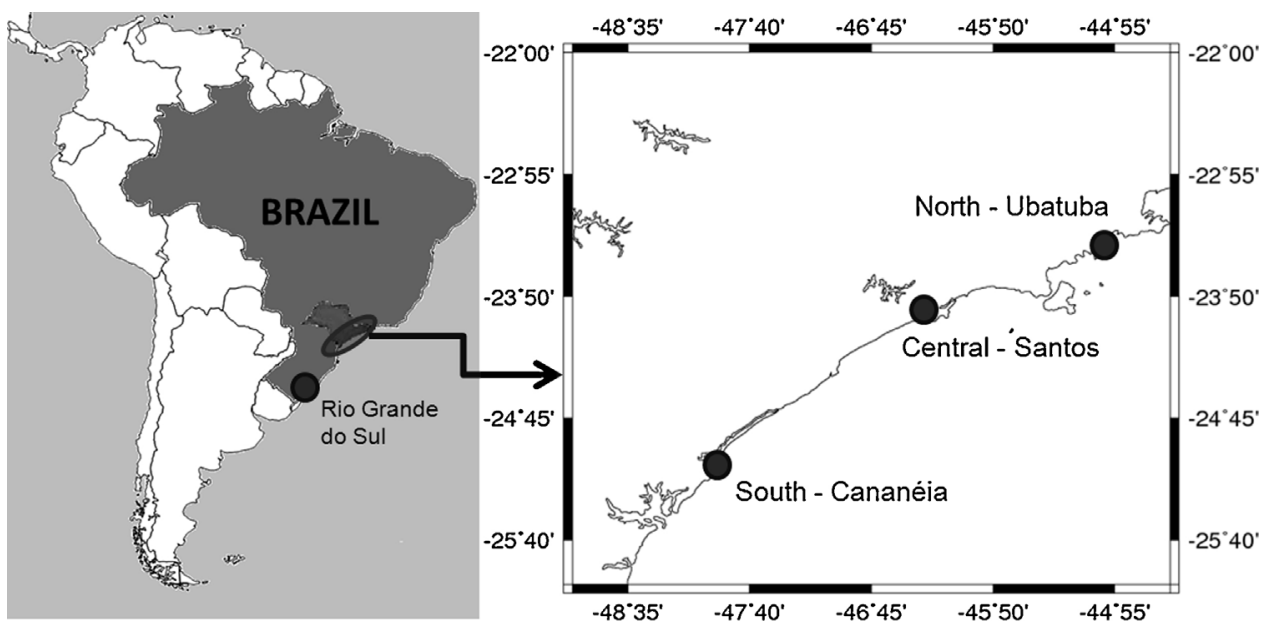

Fig. 2. Map showing the four localities of the specimens analysed. The three localities sampled from the São Paulo State are showed in detail.
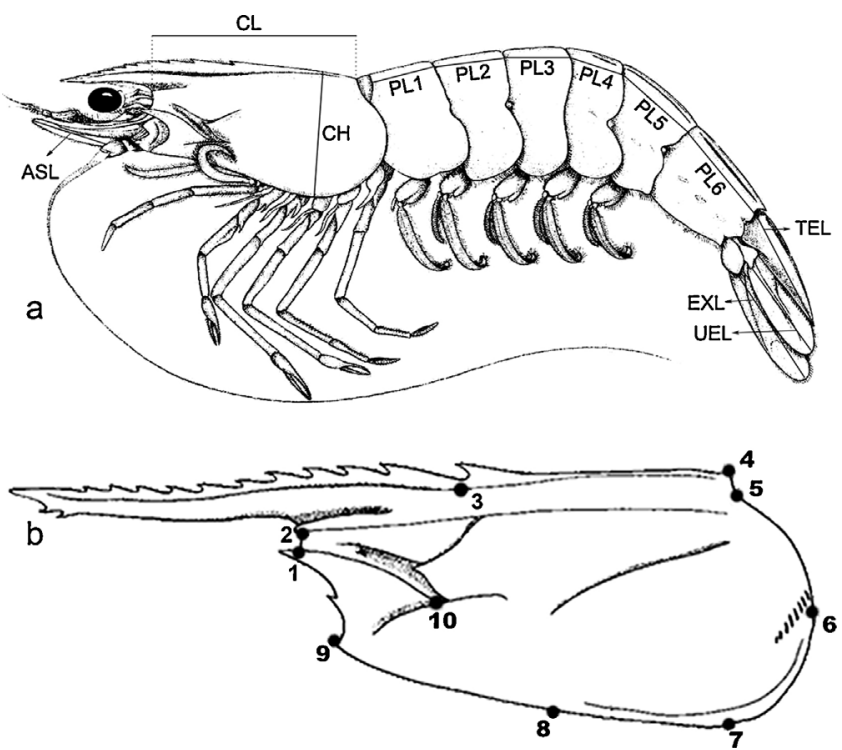

Fig. 3. Linear (A) and geometric (B) morphometrics of Farfantepenaeus brasiliensis and $F$. paulensis. A. Characterization of the measurements taken of each individual of each species: carapace length $(\mathrm{CL})$, carapace height $(\mathrm{CH})$, antennal scale length (ASL), length of the first (PL1), second (PL2), third (PL3), fourth (PL4), fifth (PL5) and sixth (PL6) pleonites, telson length (TEL), uropod endopodite length (UEL) and the uropod exopodite length (EXL). Modified from Pérez-Farfante (1969). B. Landmarks used on the carapace: 1 . intersection of anterior margin of carapace and dorsal margin of antennal spine; 2 . anterior margin of gastrofrontal carina; 3. gastrofrontal carina region, below and anterior to basal margin of epigastric tooth; 4. dorsoposterior margin of carapace; 5 . beginning of the curve of the posterior carapace margin; 6 . midway along posterior margin of carapace; 7. posterioventral margin of carapace; 8. midway along ventral margin of carapace; 9 . anterioventral margin of carapace in the pterygostomial region; and 10. intersection of ventral margin of hepatic spine and hepatic carina. Modified from Chan (2008, p. 852). Illustration by Pantaleão, J.A.F (UNESP, Bauru, Brazil).

Discriminant analysis (DA) was performed to determine which variables (body structures) were most informative. Differences among biological categories and samples were assessed with Wilks' lambda and the associated $\mathrm{F}$ and $\mathrm{P}$ statistics (Anastasiadou and Leonardos, 2008). The Wilks' lambda values can range from 0 to 1 , where $0=$ total discrimination and $1=$ non-discrimination. Additionally, a canonical discriminant analysis was performed to graphically show the separation among groups (each sex of both species). The significance of canonical variables (Roots) was examined using a Chi-square test. An analysis of covariance (ANCOVA, $\alpha=0.05$ ) was performed to compare the slope (b) and linear (a) coefficients of each morphometric relationship between the studied species.

\subsubsection{Geometric morphometry}

Digital images of the carapace side view were obtained using a Canon 60D camera coupled with a Sigma $17-50 \mathrm{~mm}$ f/2.8 lens. The distance from the camera lens to the specimen was standardized and maintained, with adjustments made to focus only. Ten anatomical landmarks were defined along the carapace margin (Fig. 3B). All of the landmarks were defined using tpsDig 2:14 software (Rohlf, 2009), following previous standardization criteria (Adams et al., 2004; Zelditch et al., 2004).

After digitizing, homologous landmarks were aligned using a generalized least-squares superimposition procedure (Procrustes analysis), and information not related to shape, such as position, orientation and scale was removed (Rohlf and Slice, 1990). The morphological variation was estimated using the thin plate spline (TPS) deformation procedure, which fits an interpolation function to a consensus configuration (Bookstein, 1997), deriving the shape variation in two main components: a uniform component (UC), describing the global variation, and a non-uniform component, describing the local variation in specific regions (Zelditch et al., 2004). Then, an analysis of relative warps (RWs), analogous to a principal component analysis, was performed on the non-uniform components, generating new shape variables (RWs) (Rohlf, 1993). All of these numerical routines were performed using tpsRelw 1.46 software (Rohlf, 2008). More detailed explanations of the morphometric methods used here can be found in Rohlf(1990), Adams et al. (2004) and Zelditch et al. (2004).

The values of the uniform components and relative warps were compared between species, separately for each sex, using a balanced multivariate analysis of variance (MANOVA - Wilks' test, $\mathrm{n}=98$ ) in Statistica 11. Centroid size (CS), defined as the square root of the summed squared distances among all landmarks and the center of gravity (centroid) of the configuration, was compared between species using Student's $t$-test. The carapace shape variation along with the relative warps, or uniform axes, was described by deformation grids obtained in the TPS analyses.

\subsection{Comparative morphology}

The purpose of the morphological analysis was to search for new characteristics that had not been identified by the techniques applied previously and/or by the current identification keys. All of the individuals whose molecular identity could be confirmed were thoroughly analyzed based on their morphology using an Olympus 
Table 1

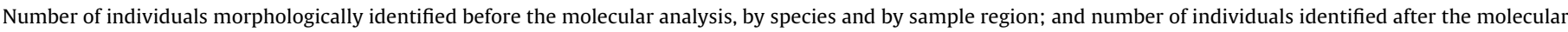
analysis. Adults: carapace length $>22 \mathrm{~mm}$; Juveniles: carapace length $<22 \mathrm{~mm}$.

\begin{tabular}{|c|c|c|c|c|c|}
\hline & \multirow[t]{2}{*}{ Regions } & \multicolumn{2}{|c|}{ Farfantepenaeus brasiliensis } & \multicolumn{2}{|c|}{ Farfantepenaeus paulensis } \\
\hline & & Adults & Juveniles & Adults & Juveniles \\
\hline \multirow{5}{*}{$\begin{array}{l}\text { Before the molecular } \\
\text { analysis }\end{array}$} & Ubatuba & 3 & 8 & 7 & 9 \\
\hline & Santos & 0 & 6 & 2 & 10 \\
\hline & Cananéia & 3 & 19 & 6 & 26 \\
\hline & Rio Grande do Sul & 0 & 0 & 4 & 0 \\
\hline & Total & 6 & 33 & 19 & 45 \\
\hline After the molecular analysis & All regions & $6\left(1 \% ; 50^{7}\right)$ & $59\left(32 q ; 27 \sigma^{7}\right)$ & $19\left(12 q ; 7 \sigma^{7}\right)$ & $19\left(50 ; 14 \sigma^{7}\right)$ \\
\hline
\end{tabular}

SZX7 stereomicroscope coupled with a light camera. This search for new characteristics was guided by studies of other species from this genus (Costa et al., 2003; Ditty and Bremer, 2011; Pérez-Farfante, 1967).

\section{Results}

\subsection{Molecular analysis}

From the 103 individuals analyzed, 39 individuals were morphologically identified as $F$. brasiliensis and 64 as $F$. paulensis (Table 1).

\subsubsection{Adults}

Molecular techniques applied to adult shrimp identified a priori by morphology confirmed that traditional criteria reliably discriminate taxa (Table 1). Based on the COI partial gene fragments from the adults of the two species ( 25 individuals, Table 1 ) and from others of the same genus used as outgroups ( $F$. californiensis, F. notialis and $F$. subtilis), nine haplotypes were defined (Fig. 4). A separation of the two species occurred, in which adults of $F$. brasiliensis formed a separate group from $F$. paulensis, but haplotypes were not distinct across sampled localities. The analysis of molecular variance (AMOVA) with simple hierarchical structure found that there is no statistically significant difference among the sample sites, either for $F$. brasiliensis (AMOVA: within regions $=99.45 \%$, among regions $=0: 55 \%, F s t=0.005, P=0.29$ ) or for $F$. paulensis (AMOVA: within regions $=103.03 \%$, among regions $=-3.03 \%$, Fst $=-0.030$, $\mathrm{P}=0.71$ ).

The number of mutations between the two species was much greater than the numbers of mutations among individuals of each species. These results were also corroborated by a genetic distance analysis: intraspecific genetic distance ( $F$. brasiliensis: 0-0.6\%; F. paulensis: 0-0.4\%) was lower than the inter-specific distance (4.3-18.1\%). Furthermore, the genetic divergence between $F$. brasiliensis and $F$. paulensis was within an interspecific divergence range (10.1-10.9\%), confirming the validity of the two species.

This initial analysis was sufficient to demonstrate that 1 ) the COI gene was effective in separating the two species; 2) the morphological characteristics used to identify adults were efficient; and 3) there was no genetic structure among regions within each species (Fig. 4). Thus, considering the confirmation of such aspects, as the focus of this study was to verify the identity of juveniles, efforts were directed toward the followed steps for obtaining sequences of individuals with $\mathrm{CL}<22 \mathrm{~mm}$, regardless of the localities, in the following analysis.

\subsubsection{Adults + Juveniles}

In total, 33 juveniles that were morphologically identified as $F$. brasiliensis and 45 juveniles that were morphologically identified as $F$. paulensis were sequenced. After the prior analysis with adults, we included juveniles in a new haplotype network (with adults and juveniles together), because there was a clear separation from other species of Farfantepenaeus (used as outgroups) in the adult analysis (Fig. 4).

Based on the partial COI gene fragments of the 103 analyzed individuals ( 25 adults and 78 juveniles), 31 haplotypes were defined, of which 25 represented haplotypes of $F$. brasiliensis and 6 represented haplotypes of $F$. paulensis (Fig. 5). This haplotype network of juveniles indicated that there is haplotype sharing among individuals morphologically classified into two different species (Fig. 5). In this analysis, we found that only 50 juveniles (approximately 64\%) were identified correctly (Fig. 5): 1 specimen that was morphologically identified as $F$. brasiliensis was actually $F$. paulensis, and 27 specimens that were morphologically identified as $F$. paulensis were actually $F$. brasiliensis. Consequently, about $50 \%$ of the $F$. brasiliensis were misidentified as F. paulensis. Additionally, a single specimen of Farfantepenaeus subtilis (Pérez-Farfante, 1967) from Cananéia-SP (CCDB 4676) was identified based on the COI gene. The obtained sequence was compared with other from one specimen collected in Alagoas (CCDB 4717), resulting in an genetic divergence of $0.2 \%$; it was also very different from $F$. brasiliensis (10.1-10.6\%) and F. paulensis (9.2-9.6\%)

\subsection{Morphometric analyses}

\subsubsection{Linear Morphometry (Adult + Juveniles)}

In total, 65 individuals that were molecularly identified as $F$. brasiliensis ( 33 females and 32 males) and 38 individuals that were molecularly identified as $F$. paulensis ( 17 females and 21 males) (Table 1) were used for morphometric analysis. The CL ranged from 12.5 to $26.9 \mathrm{~mm}$ in $F$. brasiliensis and from 9.4 to $49.5 \mathrm{~mm}$ in $F$. paulensis. Adults were included in the morphometric analysis because the intention was to find a characteristic that was reliable for the identification of both juvenile and adult specimens. A characteristic that is reliable for juveniles and adults would be very helpful and facilitate identification in field studies. Additionally, because morphometric techniques could be applied only in individuals for which the molecular identity was confirmed, the inclusion of adults increased the amount of data analyzed, producing more robust results.

The discriminant analysis revealed statistically significant differences between the two species $(p<0.00)$ and two statistically significant roots $(\mathrm{p}<0.00$; root 1 , eigenvalue: 168.85 , canonical R: 0.99, Wilks' lambda: $0.00, \chi^{2}$ : 761.17; root 2 , eigenvalue 8.49 , canonical R: 0.95 , Wilks' lambda: $\left.0.05, \chi^{2}: 275.92\right)$. Scores of the canonical variables (Roots 1 and 2 ) for males and females of both species are presented in Fig. 6. A complete separation of the categories (males and females of each species) with no intersection among groups was formed (Fig. 6).

Regarding morphometric relationships between males of $F$. brasiliensis and $F$. paulensis, the following variables presented statistically significant differences (ANCOVA, $\alpha=0.05$ ): PL2, PL3, PL5, PL6 and TEL. For females of the two species, there were statistically significant differences in the variables PL1, PL2, PL3, PL5, PL6, TEL, UEL and EXL (Fig. 3a). 


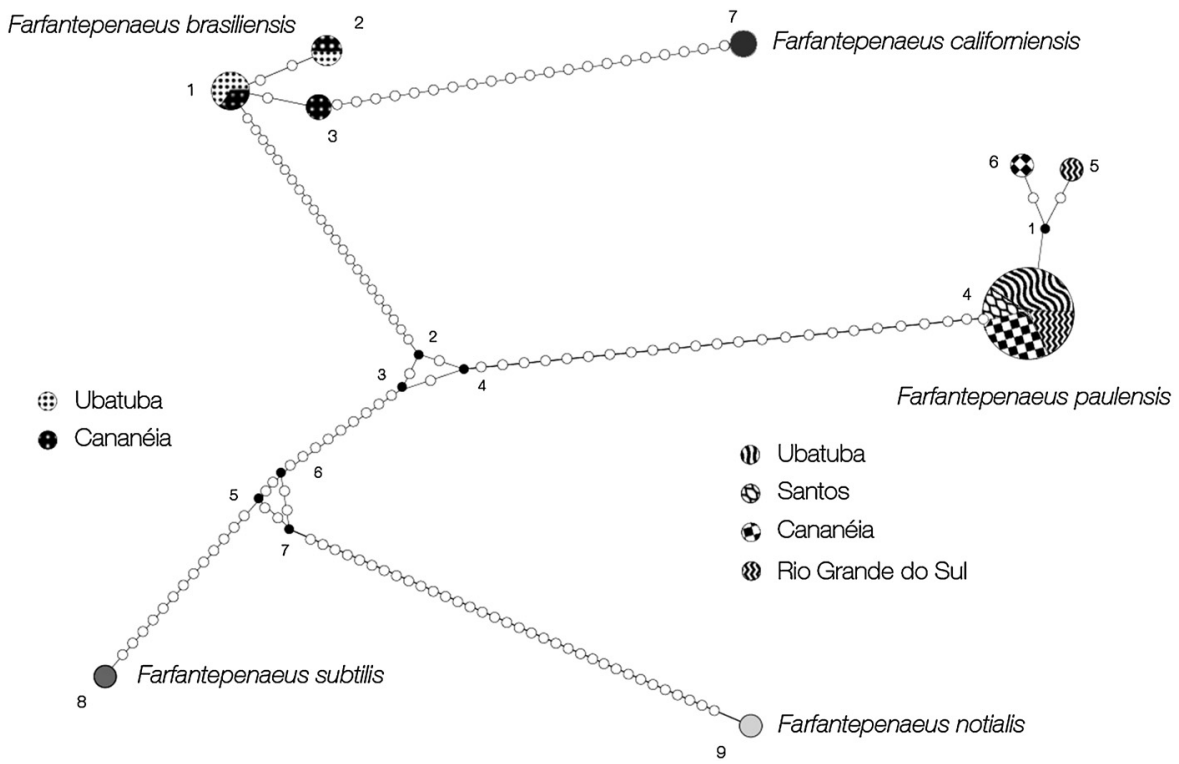

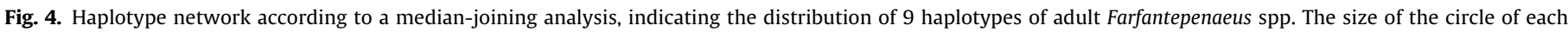
haplotype is proportionate to its frequency in the sample. The small black circles represent the mean vectors. The white circles represent mutational steps.

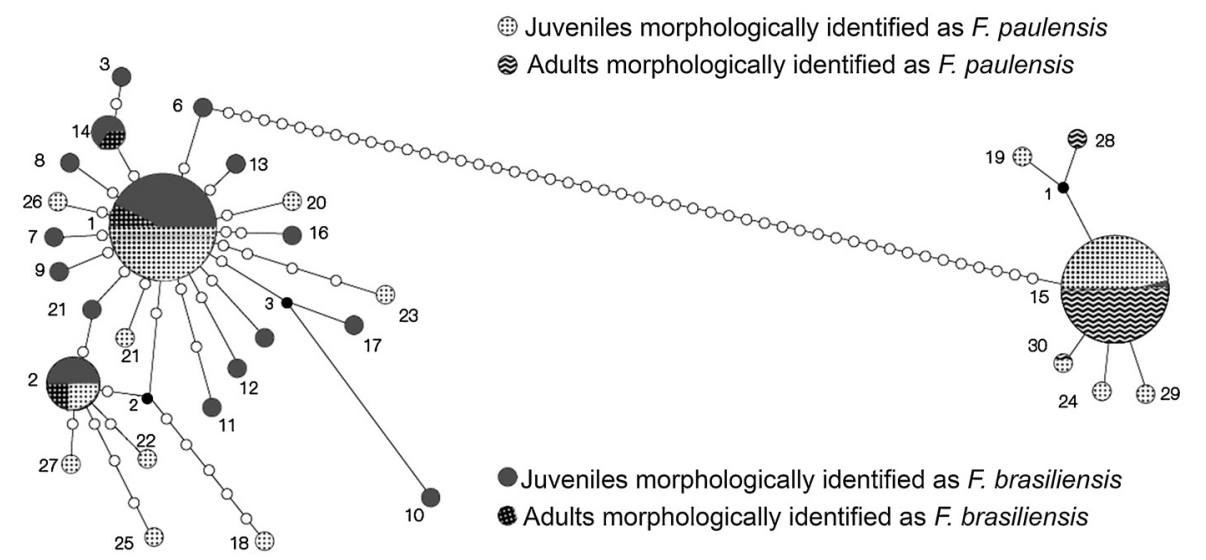

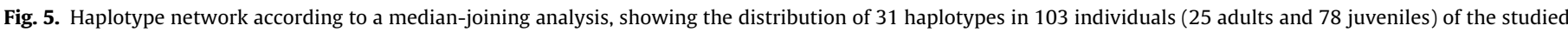

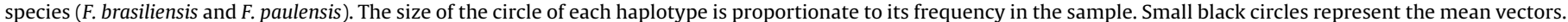
White circles represent mutational steps.

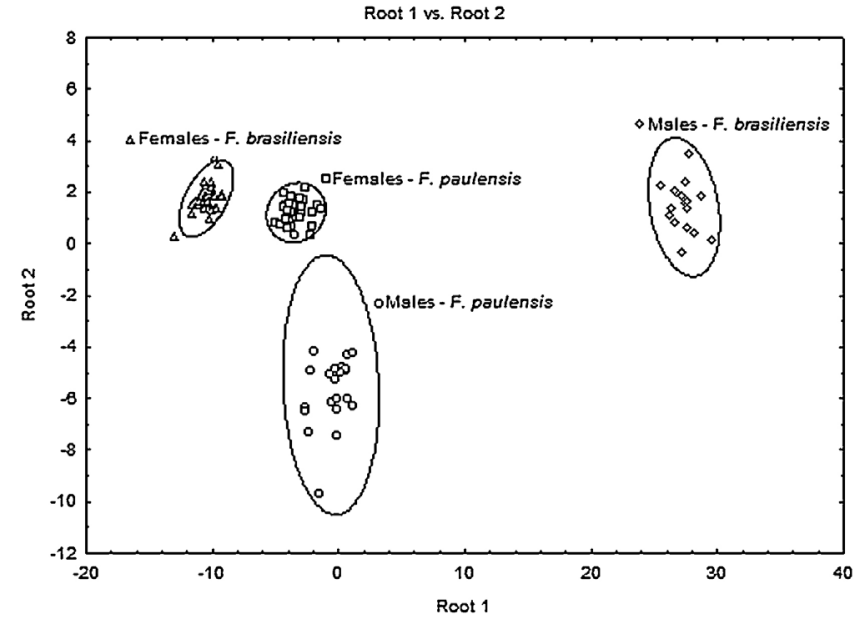

Fig. 6. Farfantepenaeus brasiliensis and F. paulensis, considering only molecular identification. Graphic generated from the relationship between two variables (canonical discriminants) for the two studied species.

\subsubsection{Geometric morphometry}

The geometric morphometry calculations were performed separately for males and females to identify shape differences between the two species. The analysis of the carapace shape of individuals of $F$. brasiliensis and $F$. paulensis resulted in 16 relative warps (RW) and 2 uniform components (UCs). For the males, the first four relative warps explained $72.6 \%$ of the total morphological variation but were not significantly different among individuals of the two species (MANOVA Wilks' test: $F=0.308, d f=16 ; 26 ; p<0.871$ ). There were also no statistically significant differences between species in uniform components (MANOVA Wilks' test: $F=0.245, d f=2 ; 40$; $p<0.784)$ or in the centroid size $(t=1.345, p<0.186)$. Among the females, none of the shape variables differed significantly between species (RW: MANOVA Wilks' test, $F=1.513, d f=4,40, p<0.217 / \mathrm{UC}$ : MANOVA Wilks' test, $F=2.574, d f=2 ; 42 ; p<0.088)$. For both males and females, no statistically significant differences were found in the carapace shape between the two species. There was no clear separation between the two species in either sex, and the extreme shapes for each category did not indicate morphological variations that could be used as criteria to discriminate between the two species. The morphological variation found for both sexes was very 


\section{Farfantepenaeus brasiliensis}

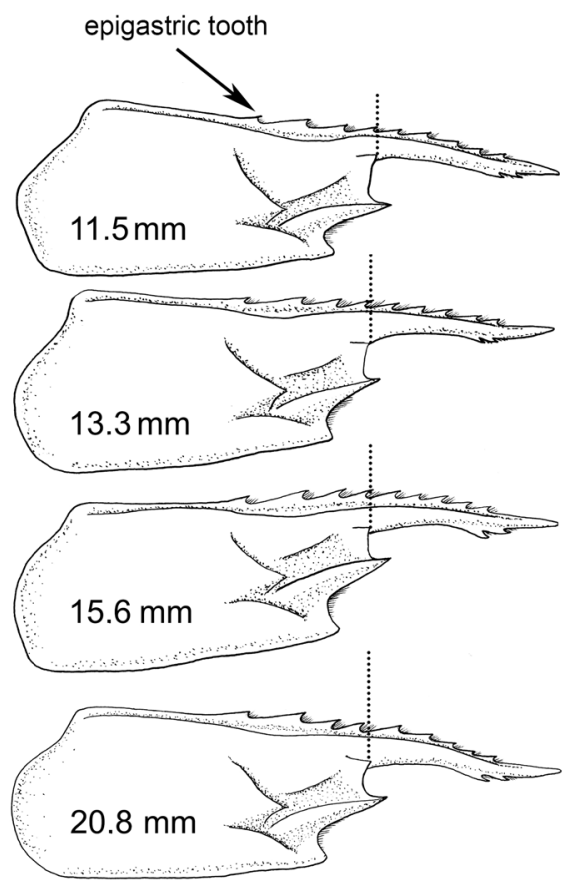

Farfantepenaeus paulensis

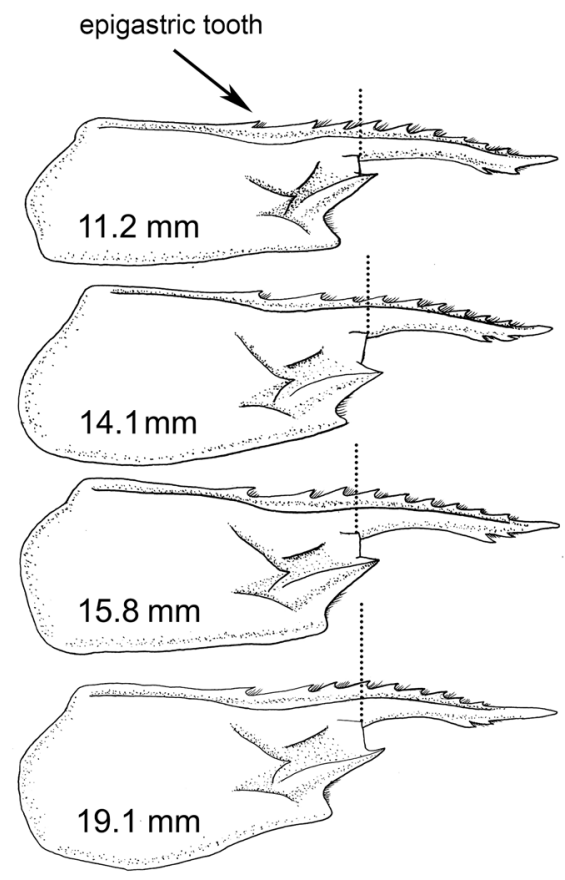

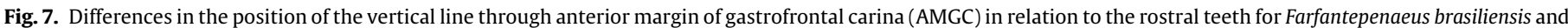

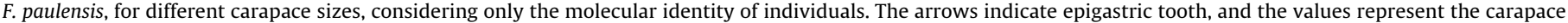
length ( $\mathrm{mm}$ ). Illustrations by JAF Pantaleão (UNESP, Bauru, Brazil).

large, as the two main axes explained only slightly more than half of the total variation in the shape $(51.1 \%$ for males and $53.4 \%$ for females).

\subsection{Comparative morphology}

Considering that the morphometric analysis (both traditional and geometric) did not indicate visual structures that could aid in species discrimination (separation was only statistical, not visual), individuals with a confirmed molecular identity were morphologically compared. In this comparative analysis, differences between the two species could be observed in the anterior margin of gastrofrontal carina in relation to the rostral teeth (Fig. 7). Considering only rostral teeth, i.e., excluding the epigastric tooth, a vertical line through anterior margin of gastrofrontal carina (AMGC) in Farfantepenaeus brasiliensis is always aligned with the 3rd rostral tooth, never anterior to it, and often close to or posterior to the end of the 3th rostral tooth (Fig. 7). In contrast, the end of the AMGC in F. paulensis is always anterior to the end of the 2 nd rostral tooth (Fig. 7).

\section{Discussion}

We confirmed the initial hypothesis that the morphological characteristics traditionally used to discriminate juveniles of $F$. brasiliensis and $F$. paulensis are not effective, and the techniques used in our study reinforced this. The molecular results showed that only approximately $64 \%$ of the juveniles identified a priori by morphology were identified correctly. This finding is novel for southwestern Atlantic penaeid populations. Similar identification problems and error rates occur with the congeners $F$. aztecus and F. duorarum from the Gulf of Mexico, where molecular identification indicated that over $30 \%$ of individuals had been misidentified (Ditty and Bremer, 2011). Additionally, we found that morphome- tric techniques did not aid in discrimination of $F$. brasiliensis and $F$. paulensis due to plasticity in morphology.

Regarding the sampling sites, there was no genetic separation between the two species, a fact supported by the genetic divergence, haplotype networks and AMOVA. Such result is reasonable since there are no geographical barriers or habitat disjunction that might serve as a barrier to gene flow among sampled localities. The possible consequences for this homogeneity were recently discussed in Teodoro et al. (2015).

The structures identified by linear morphometry that were significantly different among the individuals analyzed here were unfortunately very visually subjective and are thus unreliable for discriminating between $F$. brasiliensis and $F$. paulensis. This variability in the morphometric data may also reflect fluctuations in the allocation of energy by individuals (Pérez-Castañeda and Defeo, 2002). Environmental conditions can induce differences in shrimp development rates and phenotype, so that variations during development can alter morphology (Swain and Foote, 1999; Ditty and Bremer, 2011). In many cases in which it was assumed that the cause of morphometric variance was genetic, culturing individuals of the same group under a variety of experimental conditions resulted in different allometric growth patterns (Dumont and D'Incao, 2010). Morphometric variations can be affected by many factors, such as food availability, stress and particular stages of the reproductive cycle (Chu et al., 1995; Pauly, 1984). Discrimination of morphologically similar species, especially those of commercial value, is essential, and criteria should be effective and easily applied.

Morphological and morphometric characteristics of the rostrum have been widely used to identify penaeid shrimp species, especially juveniles (Dall et al., 1990; Ditty and Bremer, 2011; Heales et al., 1985; May-Kú et al., 2005). Geometric morphometry could only substantiate that morphological variability is too high for any measurement to be of value in discrimination. When observing the external morphology of juveniles of both species, we found differ- 

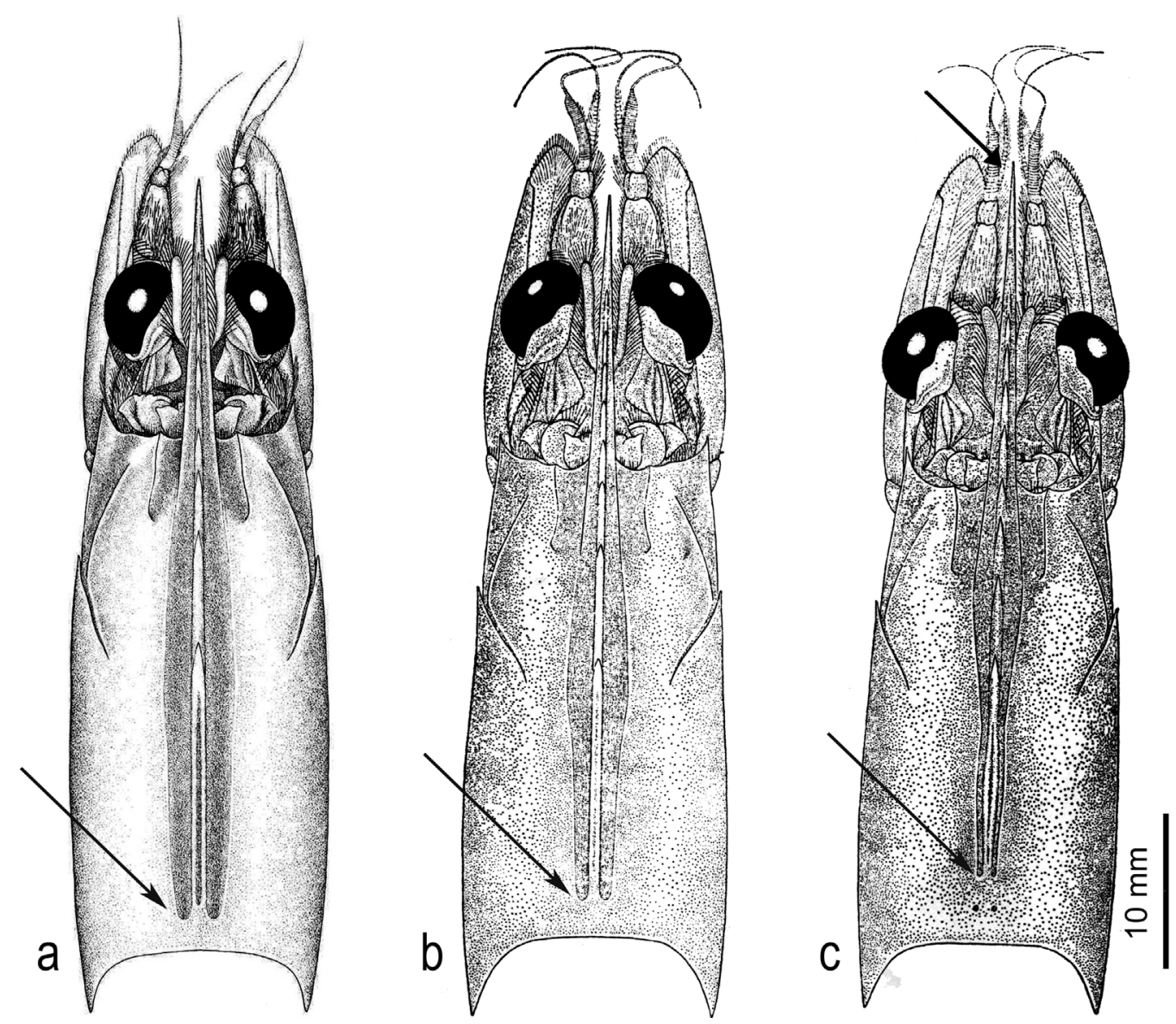

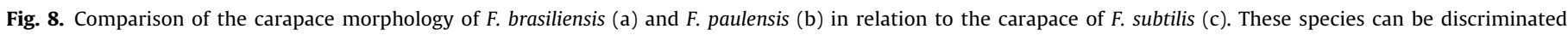

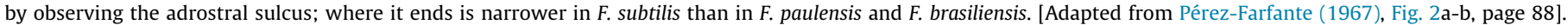

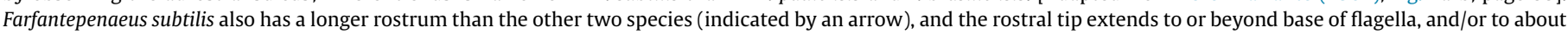
distal margin of scaphocerite.

ences in the position of the AMGC in relation to the rostral teeth (Fig. 7). However, we must consider that the position of the AMGC represents a new discriminatory characteristic that is useful only for the two species analyzed here because other species of Farfantepenaeus may have similar AMGC positions. The choice of such a characteristic is reliable for discrimination, considering that $F$. brasiliensis and $F$. paulensis were, until the present study, the only species of this genus to occur between the regions of São Paulo and Rio Grande do Sul. Because a characteristic may not be reliable for juvenile discrimination at the species level when used alone, all of the known characteristics must be used: the sixth pleonite furrow (Fig. 1) and the position of the AMGC (Fig. 7).

The correct identification of the species is a premise for all biodiversity knowledge and is essential for basic biology research, such as ecological investigations of population dynamics studies, impacts of overfishing and estimates of fishing landings (PérezFarfante, 1998). In this worrying scenario, over less than 40 years, an $87 \%$ reduction in the populations of $F$. brasiliensis and $F$. paulensis has been recorded (Neto and Dornelles, 1996); therefore, a better understanding of the structure of this stock is urgently needed, not only due to its high commercial value but also due to the need to implement more effective management plans, especially regarding the crucial populations of juveniles. The integration of molecular taxonomy and comparative morphology can provide important information on diversity patterns and on ecological and evolutionary principles relevant to fisheries management (Ditty and Bremer, 2011). The identification and knowledge of shrimp stocks must be based on more than a single method and should be composed of other approaches of stock discrimination, such as life history (growth rate, recruitment, etc.), genetic analysis and laboratory studies, such as larval-stage culture (Begg and Waldman, 1999; Cadrin, 2000; Paramo and Saint-Paul, 2010).

\subsection{Extension of the distribution of $\mathrm{F}$. subtilis}

The known geographic distribution of $F$. subtilis was extended in this study with a new record from Cananéia $\left(25^{\circ} \mathrm{S}\right)$, on the southern coast of São Paulo State. The reported distribution of $F$. subtilis ranges from Cuba $\left(23-19^{\circ} \mathrm{N}\right)$ along the arc of the Antilles to Cabo Frio (22॰ S - Rio de Janeiro, Brazil) (Pérez-Farfante, 1967). Because there are no geographic barriers between the states of São Paulo and Rio de Janeiro, the southern extension of its distribution is not surprising, and we expect other reports in other regions of southern Brazil when more accuracy and caution in species identification are applied.

Our finding reinforces the need for more reliable characteristics for the discrimination of pink shrimp species. This is why the observation of several morphological criteria is so important: for instance, if we analyze only the sixth pleonite furrow, misidentification of $F$. paulensis as $F$. subtilis may occur. Thus, considering the extremely similar morphology among species, we suggest that the AMGC position must be used to discriminate juveniles only after confirming that the individual is not $F$. subtilis (Fig. 8). Differences in shape of the carapace dorsal furrow can be used to easily separate $F$. subtilis from $F$. brasiliensis and $F$. paulensis. Farfantepenaeus subtilis has a longer rostrum than the other two species, and the ros- 
tral tip extends to or beyond base of flagella, and/or to about distal margin of scaphocerite. There is also a difference in the distance between termination of adrostral sulcus and carapace termination (Fig. 8). Finally, our molecular comparison eliminates doubt about the identification of the specimen collected in Cananéia, confirming the geographical extension.

\section{Conclusion}

The use of molecular techniques allows for precise species identification; however, due to the high costs associated with these techniques, traditional approaches to species recognition are still needed. The integration of molecular techniques and comparative morphology, as performed in this study, can provide valuable information about the diversity of patterns and fishing resources. There is literature available to assist in identification of $F$. brasiliensis when compared with certain other species of this genus and reports that show differences between $F$. paulensis and other species; however, the characteristics indicated by these studies do not aid in the discrimination between juveniles of $F$. paulensis and $F$. brasiliensis. As far as we know, there are no studies comparing juveniles of $F$. paulensis and $F$. brasiliensis or providing reliable characteristics for discriminating between these two species with highly similar morphologies. Thus, the results of this study confirm the difficulty of identifying these two species and provide morphological characteristics that are reliable for use in discriminating between $F$. brasiliensis and $F$. paulensis.

\section{Acknowledgments}

This paper is part of the multidisciplinary research project Temático BIOTA-FAPESP (São Paulo Research Foundation), which aims to produce a fine-scale assessment of the marine decapod biodiversity of the State of São Paulo. Financial support for this project was provided by research grants from FAPESP (Temático Biota 2010/50188-8; grant 2011/16268-7). Additional support came from Coordenação de Aperfeiçoamento de Pessoal de Nível Superior - CAPES (Ciências do Mar II Proc. 2005/2014 - 23038.004308/2014-14). RCC (305919/2014-8) and FLM (304968/2014-5) received research scholarships from Conselho Nacional de Desenvolvimento Científico e Tecnológico CNPq, and MT is grateful to FAPESP (PD 2011/11901-3). Thanks are due to JAF Pantaleão (UNESP, Bauru, Brazil) for illustrations used in this paper (Figs. 1, 3B and 7), and TM Davanso for valuable help with morphometric analyses. We thank to LABCAM members for their help during the fieldwork and their valuable suggestions and contributions, which helped to improve this article. The reviewers made constructive comments and suggestions during the revision process. All of the experiments conducted in this study comply with current applicable state and federal laws (authorization from the Instituto Chico Mendes de Biodiversidade/ICMBio, number 11274).

\section{References}

Adams, D.C., Rohlf, F.J., Slice, D.E., 2004. Geometric morphometrics: ten years of progress following the 'revolution'. Ital. J. Zool 71, 5-16.

Anastasiadou, C., Leonardos, I.D., 2008. Morphological variation among populations of Atyaephyra desmarestii (Millet, 1831) (Decapoda: caridea: Atyidae) from freshwater habitats of northwestern Greece. J. Crustac. Biol. 28, 240-247.

Bandelt, H.J., Forster, P., Röhl, A., 1999. Median-joining networks for inferring intraspecific phylogenies. Mol. Biol. Evol 16, 37-48.

Begg, G.A., Waldman, J.R., 1999. An holistic approach to fish stock identification. Fish. Res. 43, 35-44.

Bookstein, F.L., 1997. Morphometric Tools for Landmark Data: Geometry and Biology. Cambridge University Press, Cambridge.

Brisson, S., 1981. Estudo da população de peneídeos da área de Cabo Frio. IV-Limite da penetração das Post-Larvas de camarão-rosa na Laguna de Araruama. Institute Pesq, Publ. Mar. 141, 1-11.
Burkenroad, M.D., 1939. Further observations on Penaeidae of the northern Gulf of Mexico. Bull. Bingham Oceanogr. Collect. 6, 1-62.

Cadrin, S.X., 2000. Advances in morphometric analysis of fish stock structure. Rev, Fish Biol. Fish. 10, 91-112.

Carvalho-Batista, A., Negri, M., Pileggi, L.G., Castilho, A.L., Costa, R.C., Mantelatto, F.L., 2014. Inferring population connectivity across the range of distribution of the stiletto shrimp Artemesia longinaris Spence Bate, 1888 (Decapoda, Penaeidae) from DNA barcoding: implications for fishery management. ZooKeys 457, 271-288.

Chagas-Soares, F., Pereira, O.M., Santos, E.P., 1995. Contribuição ao ciclo biológico de Penaeus schmitti Burkenroad, 1936, Penaeus brasiliensis Latreille, 1817 e Penaeus paulensis Pérez-Farfante, 1967, na região Lagunar-Estuarina de Cananéia, São Paulo, Brasil. Institute Pesca, Bol. 22(1), 49-59.

Chan, T.Y., 2008. Shrimps and prawns: FAO species identification guide for fishery purposes. The living marine resources of the Western Pacific. Cephalopods, Crustaceans, Holothurians, and Sharks, vol. 2. FAO, Rome, pp. 687-1396.

Chu, K.H., Chen, Q.C., Huang, L.M., Wong, C.K., 1995. Morphometric analysis of commercially important penaeid shrimps from the Zhujiang estuary, China. Fish. Res. 23, 83-93.

Costa, R.C., Fransozo, A., Melo, G.A.S., Freire, F.A.M., 2003. An illustrated key for Dendrobranchiata shrimps from the northern coast of São Paulo, Brazil. Biota. Neotrop. 3, 1-12.

Costa, R.C., Lopes, M., Castilho, A.L., Fransozo, A., Simões, S.M., 2008. Abundance and distribution of juvenile pink shrimps Farfantepenaeus spp. in a mangrove estuary and adjacent bay on the northern shore of São Paulo State, southeastern Brazil. Inver. Rep. Dev. 52, 51-58.

Dall, W., Hill, B.J., Rothlisberg, P.C., Staples, D.J., 1990. The biology of the penaeidae. In: Blaxter, J.H.S., Southward, A.J. (Eds.), Advances in Marine Biology, 27 (2. Academic Press, San Diego, pp. 1-489.

Ditty, J.G., Bremer, J.R.A., 2011. Species discrimination of postlarvae and early juvenile brown shrimp (Farfantepenaeus aztecus) and pink shrimp (F. duorarum) (Decapoda: penaeidae): coupling molecular genetics and comparative morphology to identify early life stages. J. Crust Biol. 31, 126-137.

Dumont, L.F.C., D’Incao, F., 2010. Biometric relationships of the Argentinean prawn Artemesia longinaris (Decapoda: penaeidae) in the south-western Atlantic. J. Mar. Biol. Assoc. 90, 1385-1393.

Excoffier, L., Smouse, P.E., Quattro, J.M., 1992. Analysis of molecular variance inferred from metric distances among DNA haplotypes: application to human mitochondrial DNA restriction data. Genetics 131, 479-491.

Excoffier, L., Laval, G., Schneider, S., 2005. Arlequin (version 3.0): an integrated software package for population genetics data analysis. Evol. Bioinform. Online $1,47-50$.

Gusmão, J., Lazoski, C., Solé-Cava, A.M., 2000. A new species of Penaeus (Crustacea: penaeidae) revealed by allozyme and cytochrome oxidase I analyses. Mar. Biol. $137,435-446$.

Hall, T.A., 1999. BioEdit: a user-friendly biological sequence alignment Editor and analysis program for Windows 95/98/NT. Nucleic Acids Symp. Ser. 41, 95-98.

Heales, D.S., Polzin, H.G., Staples, D.J., 1985. Identification of the postlarvae of the commercially important Penaeus species in Australia. In: Rothlisberg, P., Hill, B., Staples, D. (Eds.), Second Australian National Prawn Seminar (Seminar Sponsor, Cleveland, Queensland, Australia). , pp. 41-46.

Hebert, P.D., Ratnasingham, S., deWaard, J.R., 2003. Barcoding animal life: cytochrome c oxidase subunit 1 divergences among closely related species. Proc. R. Soc. Lond. B. Biol. Sci. 270, S96-S99.

IBAMA, 2011. Instituto Brasileiro do Meio Ambiente e dos Recursos Naturais Renováveis. Boletim Estatístico da Aquicultura e Pesca no Brasil -ano 2011. Brasil, 60p. Available at. http://www.mpa.gov.br/index.php/informacoes-eestatisticas/estatistica-da-pesca-e-aquicultura (accessed: 13.01.14.).

Ives, J.E., 1891. Crustacea from the northern coast of Yucatan, the Harbor of Vera Cruz, the West coast of Florida and the Bermuda Islands. Proc. Acad. Nat. Sci. Philadelphia 1891, 177-207.

Kimura, M., 1980. A simple method for estimating evolutionary rates of base substitutions through comparative studies of nucleotide sequences. J. Mol. Evol. 16, 111-120.

Latreille, P.A., 1817. Pénée. Penaeus - Nouveau Dictionnaire d'Histoire Naturelle 25, 152-156.

Lopes, M., 2012. Distribuição E Dinâmica Populacional Dos Camarões-rosa Farfantepenaeus Brasiliensis (Latreille, 1817) E F. Paulensis (Pérez-Farfante, 1967) E Do Camarão Branco Litopenaeus Schmitti (Burkenroad, 1936) (Decapoda: Dendrobranchiata: Penaeidae) No Complexo Baía-estuário De Santos-São Vicente, São Paulo, Brasil: Subsídios Científicos Para a Averiguação Do Período Ideal De Defeso. Doctoral Thesis (unpublished). Universidade Estadual Paulista, Botucatu, SP.

Mantelatto, F.L., Robles, R., Felder, D.L., 2007. Molecular phylogeny of the western Atlantic species of the genus Portunus (Crustacea Brachyura, Portunidae). Zool. J. Linn. Soc. 150, 211-220.

Mantelatto, F.L., Robles, R., Schubart, C.D., Felder, D.L., 2009. Molecular phylogeny of the genus Cronius Stimpson, 1860, with reassignment of C. tumidulus and several American species of Portunus to the genus Achelous de Haan, 1833 (Brachyura: portunidae). In: Martin, J.W., Crandall, K.A., Felder, D.L. (Eds.), Decapod Crustacean Phylogenetics. Taylor \& Francis/CRC Press, Boca Raton, pp. 567-581.

May-Kú, M.A., Ordóñez-López, U., Defeo, O., 2005. Morphometric differentiation in small juveniles of the pink spotted shrimp (Farfantepenaeus brasiliensis) and the southern pink shrimp (F. notialis) in the Yucatan Peninsula, Mexico. Fish. Bull. 104, 306-310. 
Miers, E.J., 1878. Notes on the Penæidæ in the collection of the British Museum, with descriptions of some new species. Proc. Zool. Soc. London 1878, 298-310.

Moritz, C., Dowling, T.E., Brown, W.M., 1987. Evolution of animal mitochondrial DNA: relevance for population biology and systematics. Annu. Rev. Ecol. Syst. $18,269-292$

Neto, J.D., Dornelles, L.D.C., 1996. Diagnóstico Da Pesca Marítima Do Brasil. Coleção Meio Ambiente (Séries-Estudos). IBAMA, Brasília.

Pérez-Castañeda, R., Defeo, O., 2002. Morphometric relationships of penaeid shrimps in a coastal lagoon: spatio-temporal variability and management implications. Estuaries 25, 282-287.

Pérez-Farfante, I., Kensley, B., 1997. Penaeoid and sergestoid shrimps and prawns of the world: keys and diagnoses for the families and genera. Mém. Mus. Natl Hist. Nat 195, 1-233.

Pérez-Farfante, I., 1967. A new species and two new subspecies of shrimp of the genus Penaeus from the western Atlantic. Proc. Biol. Soc. Wash. 80, 83-100.

Pérez-Farfante, I., 1969. Western atlantic shrimps of the genus penaeus: US fish and wildlife service. Fish. Bull. 67, 461-591.

Pérez-Farfante, I., 1970. Diagnostic characters of juveniles of the shrimps Penaeus aztecus, P. duorarum, and P. brasiliensis. (Crustacea, Decapoda, Penaeidae). In: Hacker, R.L., Fukuyama, M.S. (Eds.), Special Scientific Report - Fisheries No. 599. U.S. Department of the Interior, U.S. Fish and Wildlife Service. Bureau of Commerical Fisheries, Washington, pp. 1-26.

Pérez-Farfante, I., 1971. Características diagnósticas de los juveniles de Penaeus aztecus subtilis, P. duorarum notialis y P. brasiliensis (Crustacea Decapoda Penaeidae). Mem. Soc. Ci. Nat. La Salle 30, 159-182.

Pérez-Farfante, I., 1998. Illustrated key to Penaeoid shrimps of commerce in the Americas. NOAA Tech. Rep. NMFS 64, 1-32.

Paramo, J., Saint-Paul, U., 2010. Morphological differentiation of southern pink shrimp Farfantepenaeus notialis in Colombian Caribbean Sea. Aquat. Living Resour. 23, 95-101.

Pauly, D., 1984. Fish Population Dynamics in Tropical Waters: A Manual for Use with Programmable Calculators. International Center for Living and Aquatic Resources Management, Manila, Philippines.

Rohlf, F.J., Slice, D., 1990. Extensions of the Procrustes method for the optimal 20 superimposition of landmarks. Syst. Zool. 39, 40-59.

Rohlf, F.J., 1990. Morphometrics. Annu. Rev. Ecol. Syst. 21, 299-316.

Rohlf, F.J., 1993. Relative warp analysis and an example of its application to mosquito wings. In: Marcus, L.F., Bello, E., García-Valdecasas, A. (Eds.), Contributions to Morphometrics. Museo Nacional de Ciencias Naturales, Madrid, pp. 131-159.
Rohlf, F.J., 2008. Tpsdig, version 2.12. Department of Ecology and Evolution, State University of New York at Stony Brook. Available at: http://life.bio.sunysb.edu/ morph/ (accessed 01.12.13.).

Rohlf, F.J., 2009. TpsRelw, relative warps analysis, version 1.46. Department of Ecology and Evolution, State University of New York at Stony Brook. Available at: http://life.bio.sunysb.edu/morph/ (accessed 01.12.13.).

Rozas, J., Rozas, R., 1999. DnaSP version 3: an integrated program for molecular population genetics and molecular evolution analysis. Bioinformatics 15, $174-175$.

Swain, D.P., Foote, C.J., 1999. Stocks and chameleons: the use of phenotypic variation in stock identification. Fish. Res. 43, 113-128.

Tamura, K., Peterson, D., Peterson, N., Stecher, G., Nei, M., Kumar, S., 2011. MEGA5: molecular evolutionary genetics analysis using maximum likelihood evolutionary distance, and maximum parsimony methods. Mol. Biol. Evol. 28, 2731-2739.

Teodoro, S.S.A., Terossi, M., Costa, R.C., Mantelatto, F.L., 2015. Genetic homogeneity in the commercial pink shrimp Farfantepenaeus paulensis revealed by COI barcoding gene. Est. Coast. Shelf Sci. 166, 124-130.

Terossi, M., Mantelatto, F.L., 2012. Morphological and genetic variability in Hippolyte obliquimanus Dana, 1852 (Decapoda, Caridea, Hippolytidae) from Brazil and the Caribbean Sea. Crustaceana 85, 685-712.

Thompson, J.D., Higgins, D.G., Gibson, T.J., 1994. ClustalW: improving the sensitivity of progressive multiple sequence alignment through sequence weighting specific gap penalties and weight matrix choice. Nucleic Acids Res. $22,4673-4680$

Tzeng, T., 2004. Stock identification of sword prawn Parapenaeopsis hardwickii in the East China sea and Taiwan Strait inferred by morphometric variation. Fish. Sci. 70, 758-764.

Vergamini, F.G., Pileggi, L.G., Mantelatto, F.L., 2011. Genetic variability of the Amazon river Prawn Macrobrachium amazonicum (Decapoda Caridea Palaemonidae). Contr. Zool. 80, 67-83.

Zelditch, M., Swiderski, D., Sheets, D.H., Fink, W., 2004. Geometric Morphometrics for Biologists: A Primer. Elsevier Academic Press, New York. 